\title{
ИСПОЛЬЗОВАНИЕ РОТЕNTILLA BIFURСA L. КАК ВОЗМОЖНОГО ИНДИКАТОРА ЗАГРЯЗНЕНИЯ ОКРУЖАЮЩЕЙ СРЕДЫ В ПРОМЫШЛЕННЫХ РЕГИОНАХ
}

\section{USING POTENTILLA BIFURCA L. AS A POSSIBLE INDICATOR OF POLLUTION IN INDUSTRIAL REGIONS}

\section{Yu. Kanibolotskaya}

Summary. Due to the significant impact of anthropogenic factors on the environment in man-made regions, Potentilla bifurca $\mathrm{L}$. is considered as an indicator of pollution of industrial areas by some heavy metals ( $\mathrm{Ti}, \mathrm{Mn}$, $\mathrm{Cr}, \mathrm{Fe}, \mathrm{Ni}, \mathrm{Cu}, \mathrm{Zn}, \mathrm{Pb}$ and $\mathrm{Sr}$ ). Their content in plant (P. bifurca) and soil samples selected in the suburbs of Pavlodar and Aksu (Pavlodar region, Kazakhstan) at various distances from existing industrial enterprises was analyzed; geobotanical studies have also been carried out. It was found that $\mathrm{Zn}$ and $\mathrm{Cr}$ accumulate in $\mathrm{P}$. bifurca more actively than $\mathrm{Sr}$ and $\mathrm{Mn}$, and $\mathrm{Ni}, \mathrm{Pb}, \mathrm{Cu}, \mathrm{Ti}, \mathrm{Fe}$ - in rather small quantities. There is no obvious negative effect on Potentilla bifurca of high concentrations of these metals. In this regard, Potentilla bifurca's accumulation capacity, for example, Zn and $\mathrm{Cr}$, can be used (taking into account various factors) to determine the presence of environmental pollution in man-made regions, in particular in areas where metallurgical plants are located.

Keywords: heavy metals in soil, heavy metals in vegetation, Potentilla bifurca L., biological absorption coefficient, hazard coefficient; Digressionactive species, pollution indicator.

\author{
Каниболоцкая Юлия Михайловна \\ К.б.н., дочент, Сибирский университет \\ потребительской кооперации (2. Новосибирск) \\ yu_leonova@mail.ru
}

Аннотация. В связи со значительным воздействием антропогенных факторов на окружающую среду в техногенных регионах рассматривается возможность использования Potentilla bifurca L. в качестве индикатора загрязнения промышленных территорий некоторыми тяжелыми металлами (Ti, Mn, Cr, Fe, Ni, Cu, Zn, Pb и Sr). Проанализировано их содержание в растительных (P. bifurca) и почвенных пробах, отобранных в пригородах городов Павлодара и Аксу (Павлодарская область, Казахстан) на различных расстояниях от действующих промышленных предприятий; проведены и геоботанические исследования. Выявлено, что $\mathrm{Zn}$ и $\mathrm{Cr}$ накапливаются в Р. bifurca более активно, чем $\mathrm{Sr}$ и $\mathrm{Mn}$, a Ni, $\mathrm{Pb}, \mathrm{Cu}$, Ti, $\mathrm{Fe}$ - в довольно незначительных количествах. Очевидного негативного эффекта от воздействия на Р. bifurca высоких концентраций этих металлов не наблюдается. В связи с этим способность лапчатки вильчатой к аккумуляции, например, Zn и Cr можно использовать (с учетом действия различных факторов) для определения наличия загрязнения среды в техногенных регионах, в частности, в районах расположения металлургических предприятий.

Ключевые слова: тяжелые металлы в почве, тяжелые металлы в растениях, лапчатка вильчатая, Potentilla bifurca, коэффициент биологического поглощения, коэффициент опасности, дигрессионно-активные виды, индикатор загрязнения.

зоваться всеми благами цивилизации, что подразумевает функционирование многочисленных промышленных объектов, которые и обеспечивают создание привычного для нас комфорта и удобства (напрямую - обеспечением подачи электроэнергии в наши дома, либо же в процессе производства привычных нам вещей).

Так, например, среди крупных индустриальных центров Казахстана город Павлодар, в промзонах которого - Павлодарский алюминиевый (АО «Алюминий Казахстана»), Казахстанский электролизный (КЭЗ) и нефтехимический (ПНХ3) заводы, ТЭЦ-1,2,3, Аксуский завод ферросплавов (АО ТНК Казхром), Аксуская электростанция (АО ЕЭК - Евразийская Энергетическая Корпорация), ПФ ТОО Кастинг - переплавка стали и АО Каустик (на базе ранее существовавших тракторного и химического заводов) и многие другие предприятия, является одним из самых загрязненных (Панин, 2002) [1]. 
Для определения состояния окружающей среды в таких - техногенных - регионах достаточно простым и действенным методом может стать использование живых организмов, «умеющих» жить на загрязненных территориях без потери жизнеспособности. Причем растения в этом случае более предпочтительны, поскольку они не покидают места своего обитания, как это характерно для животных либо насекомых. Используя растительные организмы в качестве индикаторов, мы можем понимать, насколько насыщена та или иная территория, допустим, тяжелыми металлами. Возможность же проводить сопоставление и анализ содержания поллютантов в нескольких средах, в нашем случае - в почве и растениях, дает для выявления «состояния здоровья» окружающей среды много больше, чем контроль аккумуляции загрязнителей, например, только почвой, т.к. появляется возможность делать более обоснованные выводы о состоянии территории.

Вопросами поглощения и накопления тяжелых металлов (TM) растениями занимаются ученые разных стран $[2,3,4,5,6,7,8,9,10,11,12]$. В основном в таких исследованиях изучается древесно-кустарниковая растительность, гораздо меньше работ, где в качестве индикаторов загрязнения среды выступали бы травы, и оценивалась трансформация растительного покрова регионов в результате влияния на него всего комплекса антропогенных факторов. Поэтому мы рассматриваем и состояние растительного покрова территорий, находящихся в зоне действия промышленных предприятий (энергетики, черной и цветной металлургии, нефтехимической промышленности) [13,14,15], и отдельные виды растений (доминанты или субдоминанты) в качестве возможных аккумуляторов поллютантов. Так, в Павлодарской области Potentilla bifurca L. часто является субдоминантом в растительных сообществах (дигрессионно-активный вид; несколько десятков лет назад, в отсутствии интенсивного антропогенного воздействия, в регионе она почти не встречалась). К тому же, $P$. bifurca достаточно стойко переносит воздействие механических антропогенных факторов, в частности - выпаса, активно здесь осуществляемого.

\section{Цель работы}

Изучить возможность использования Potentilla bifurca L. (лапчатки вильчатой) в качестве индикатора загрязнения окружающей среды в промышленных регионах.

\section{Объекты и методы}

С 2006 по 2016 год мы исследовали состояние растительного покрова нескольких районов Павлодарской области (Казахстан). Обследовано более 50 участков, вы- бранных на разных расстояниях (1-3-5-10-20-50 км на север, юг, восток и запад) от промзон городов Павлодара и Аксу, с учетом розы ветров и транспортной либо пешей доступности, согласно стандартным методическим рекомендациям [16,17]. Пробы для химических анализов отбирались в 2006, 2011, 2013, 2015-2016 годах. Почву брали из слоев 0-5 см и 10-15 см (в первом случае выявляли текущее, а во втором - многолетнее загрязнение). Точки отбора проб приурочены к преобладающим растительным сообществам, в которых проводились детальные геоботанические описания (с использованием классических методов геоботаники) [18].

Определение содержания элементов в почве и растениях осуществлялось методом рентгенофлюоресцентного анализа (для почвы - с отжигом, для растений с предварительным озолением) на РФА-спектрометре «Спектроскан GF-1E» (Россия, 2000г/в). Пробы анализировали в лаборатории Физико-технического института МОиН РК (поселок Алатау, Алма-атинская область, Казахстан). Сопоставление предельно-допустимых концентраций элементов в почве устанавливалось согласно нормативам предельно допустимых концентраций (ПДК) [19,20,21], концентрации железа в почве сравнивали с содержанием его на условно-фоновом участке.

Для почвенных проб был рассчитан коэффициент опасности $\mathrm{K}_{\text {, }}$ демонстрирующий концентрацию металла в почве в долях ПДК. коэффициент опасности определяли по формуле [22]:

$$
\mathrm{K}_{\mathrm{o}}=\frac{\mathrm{C}}{\Pi д \mathrm{~K}},
$$

где: C - фактический уровень содержания рассматриваемого элемента в почве, ПДК - предельно допустимые концентрации данного элемента в почве.

Для выявления уровня аккумуляции растениями поллютантов мы использовали $P$. bifurca, так как фитоценозы с ее участием имеют широкое распространение не только на территории наших исследований, но и во многих других регионах. В частности, этот вид лапчатки произрастает и в Новосибирской области в качестве компонента аборигенной флоры - например, по границе с Павлодарской областью, и сорного (дигрессионно-активного) вида.

Для выявления уровня перехода тяжелых металлов из почвы в растения определяли коэффициент биологического поглощения (КБП) $\mathrm{A}_{x}$ по формуле [23]:

$$
A_{x}=\frac{l_{x}}{n_{x}}
$$

где $l_{x}$ - содержание элемента х в золе растения, $n_{x}$ - содержание того же элемента в почве. Рассчиты- 


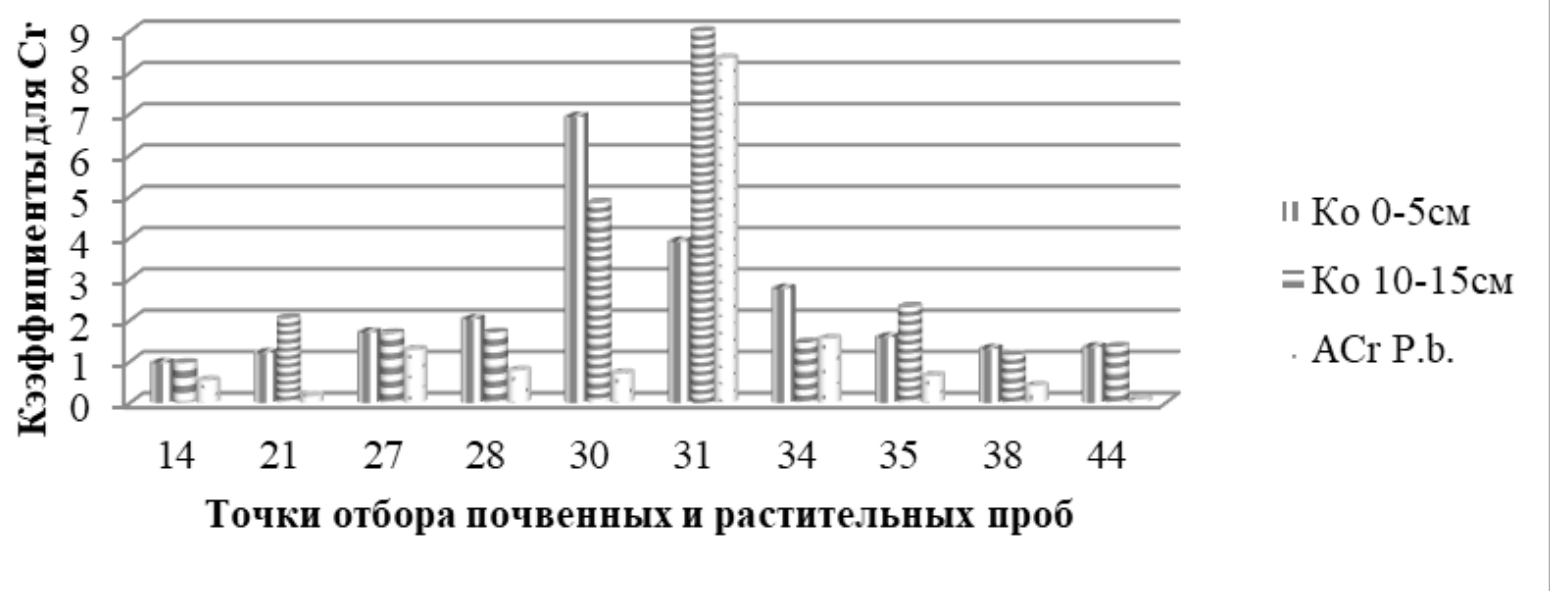

Рис. 1. Относительные концентрации $\mathrm{Cr}$ в почве $\left(\mathrm{K}_{o}\right)$ и растениях ( $\mathrm{A}_{C r}$ Potentilla bifurca)

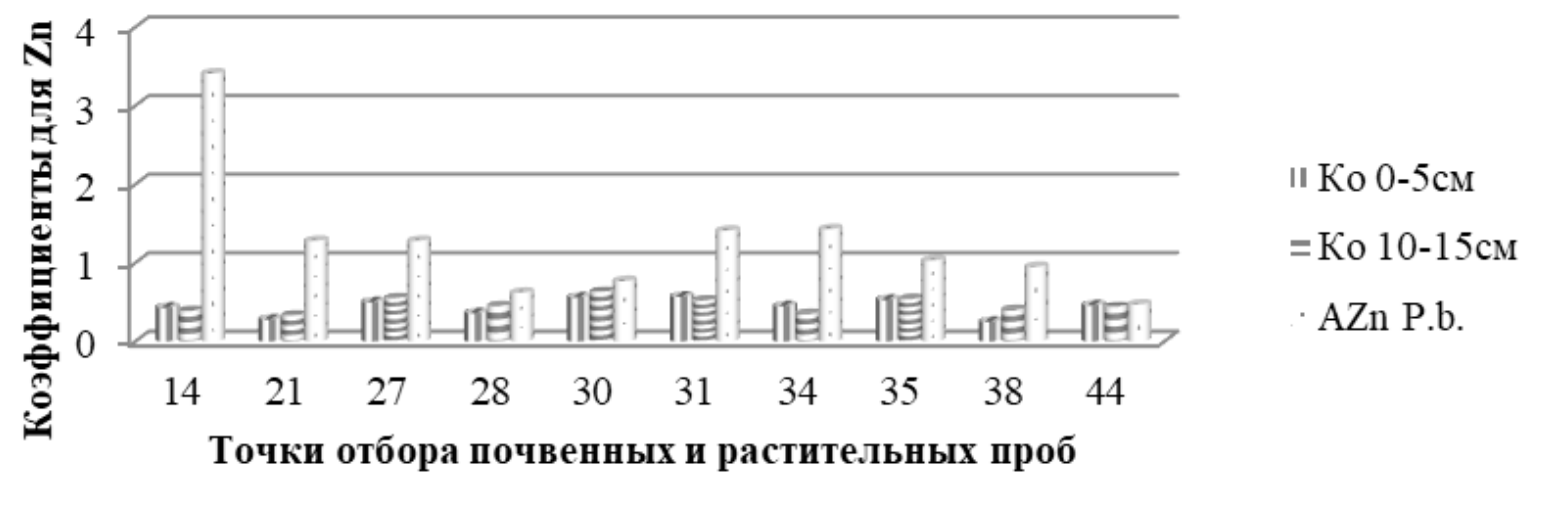

Рис. 2. Относительные концентрации $\mathrm{Zn}$ в почве $\left(\mathrm{K}_{o}\right)$ и растениях ( $\mathrm{A}_{Z n}$ Potentilla bifurca)

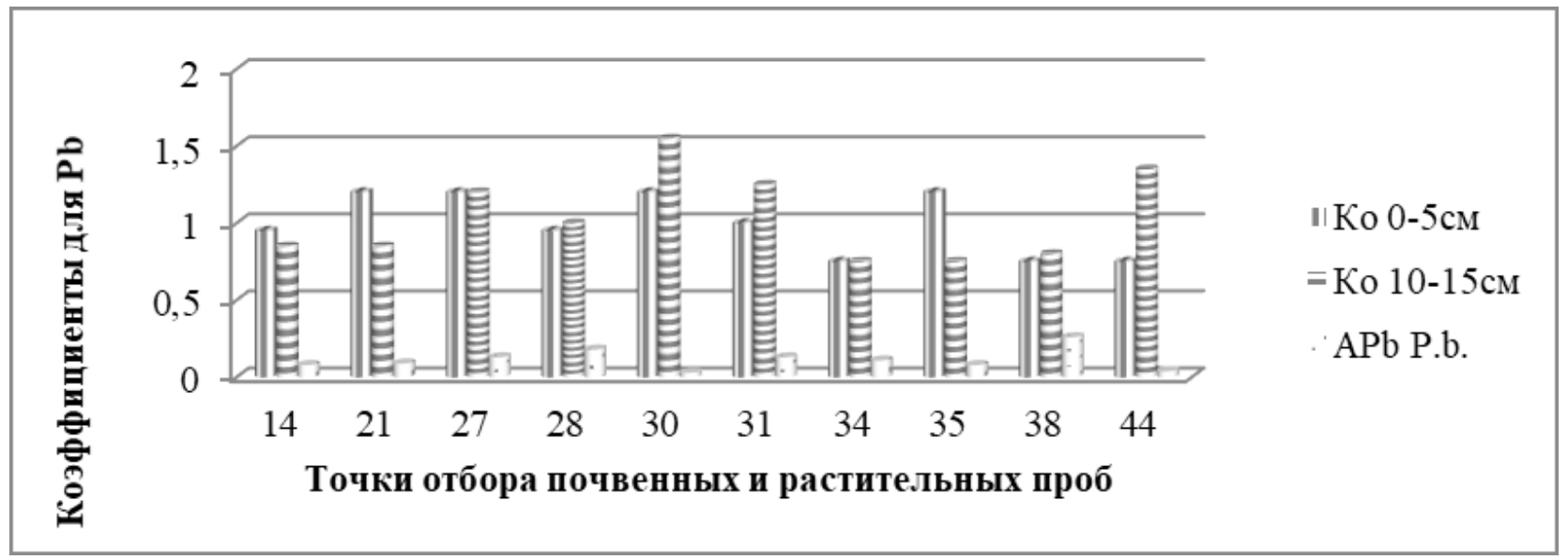

Рис. 3. Относительные концентрации $\mathrm{Pb}$ в почве $\left(\mathrm{K}_{o}\right)$ и растениях ( $\mathrm{A}_{P b}$ Potentilla bifurca) 


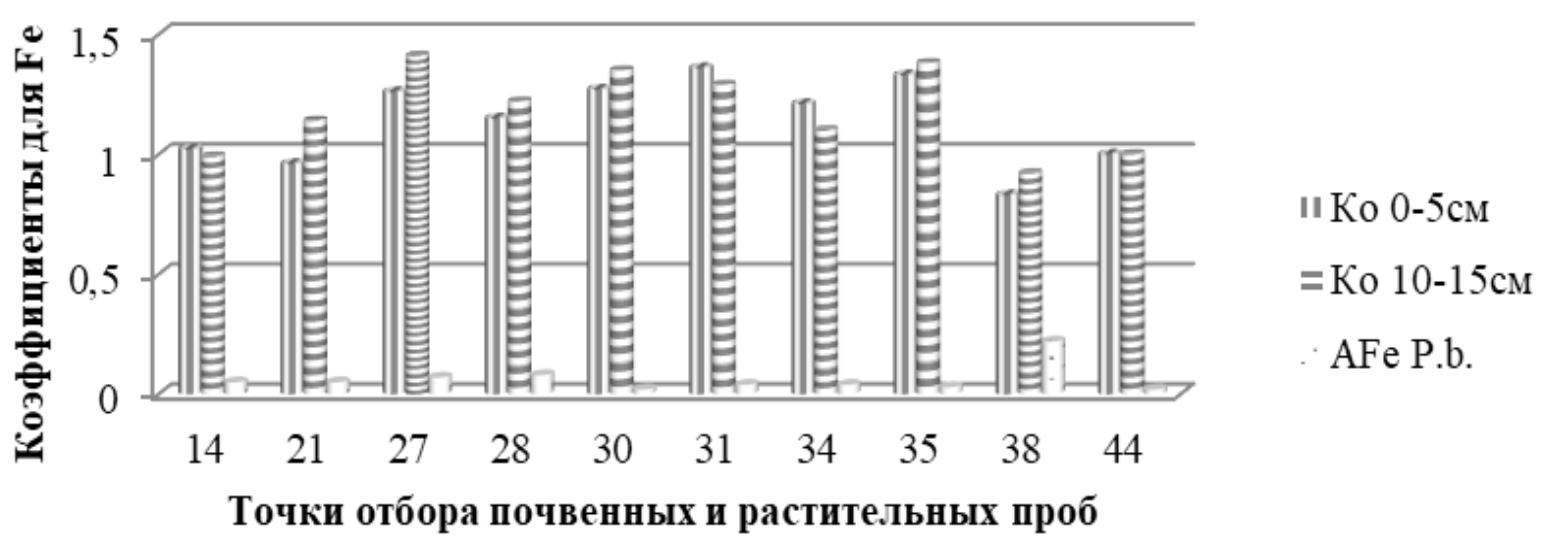

Рис. 4. Относительные концентрации Fе в почве $\left(\mathrm{K}_{o}\right)$ и растениях $\left(\mathrm{A}_{F e}\right.$ Potentilla bifurca)

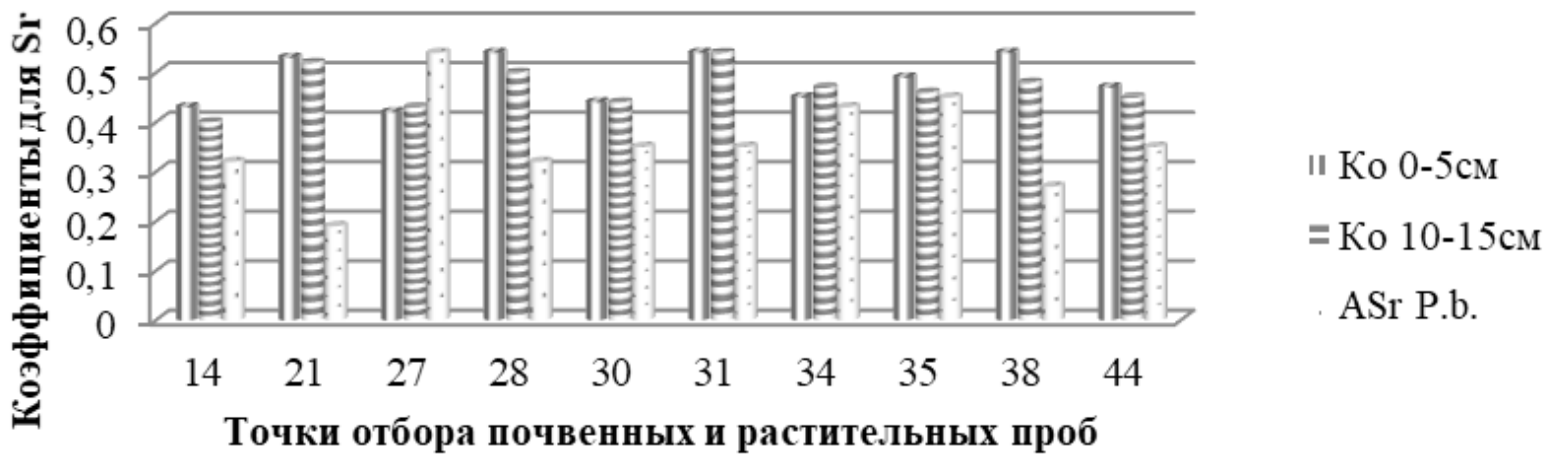

Рис. 5. Относительные концентрации Sr в почве $\left(\mathrm{K}_{o}\right)$ и растениях $\left(\mathrm{A}_{S r}\right.$ Potentilla bifurca)

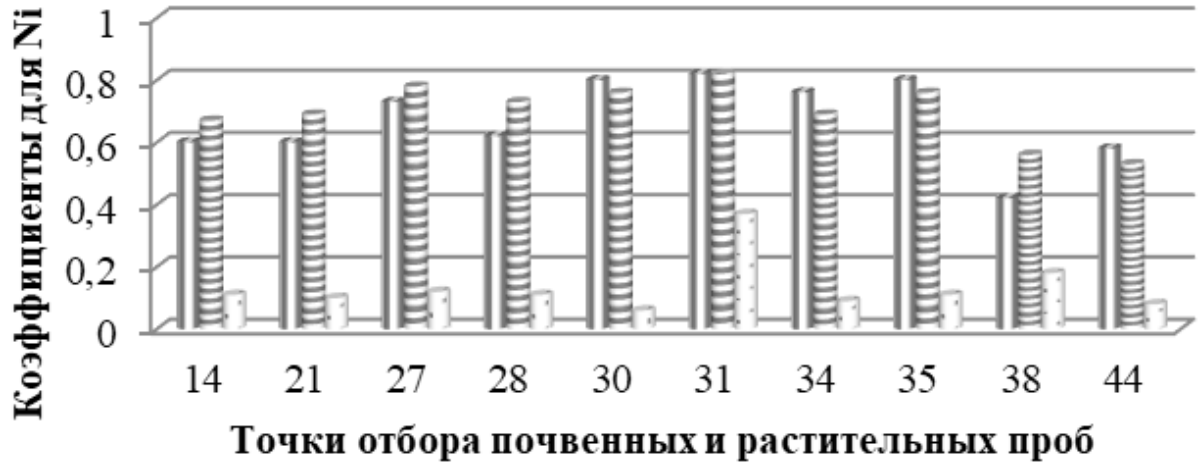

II Ko $0-5 \mathrm{~cm}$

$=$ Ko $10-15 \mathrm{~cm}$

ANi P.b.

Рис. 6. Относительные концентрации Ni в почве $\left(\mathrm{K}_{o}\right)$ и растениях ( $\mathrm{A}_{N i}$ Potentilla bifurca) 


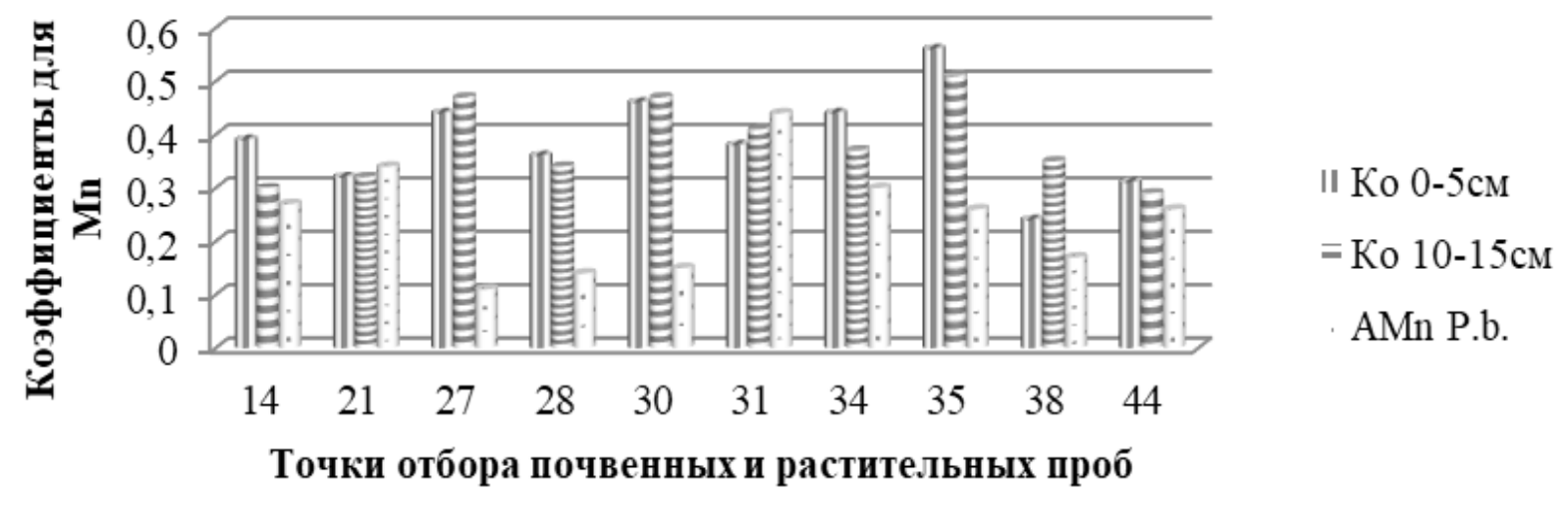

Рис. 7. Относительные концентрации $\mathrm{Mn}$ в почве $\left(\mathrm{K}_{o}\right)$ и растениях $\left(\mathrm{A}_{M n}\right.$ Potentilla bifurca)

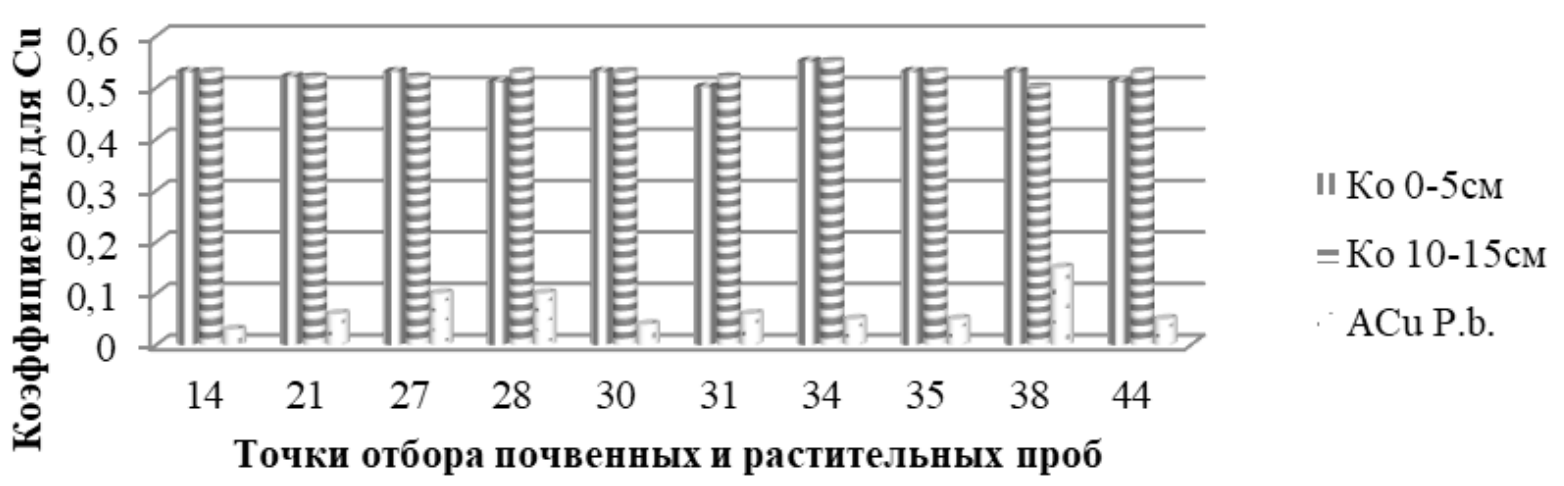

Рис. 8. Относительные концентрации Си в почве $\left(\mathrm{K}_{o}\right)$ и растениях ( $\mathrm{A}_{C u}$ Potentilla bifurca)

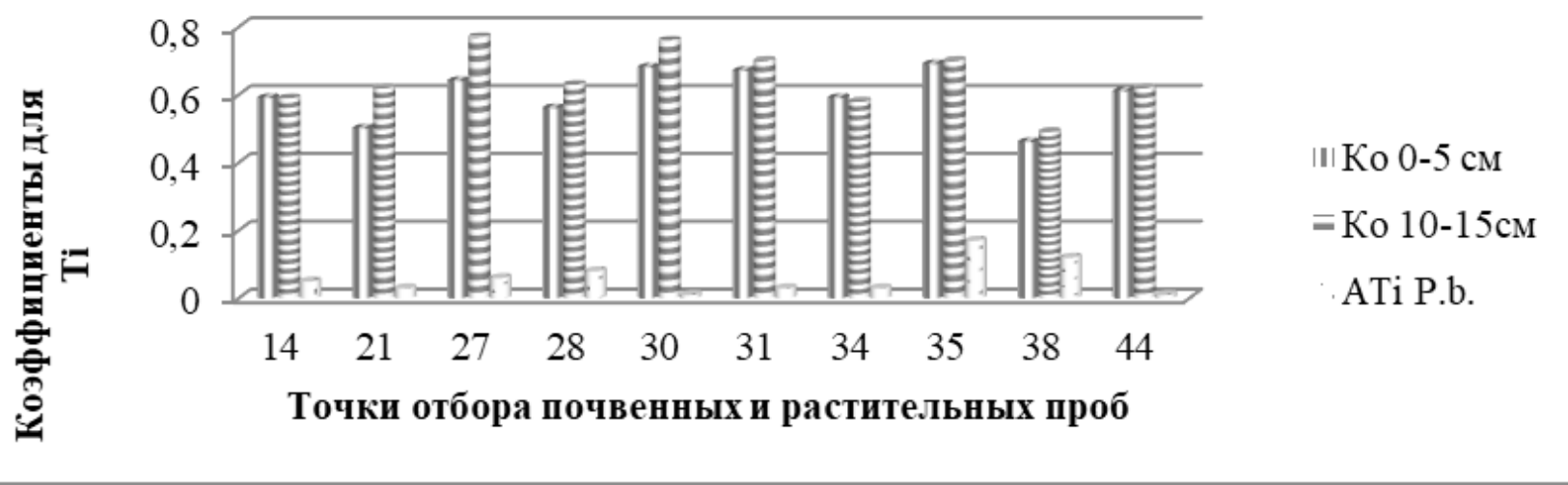

Рис. 9. Относительные концентрации Ті в почве $\left(\mathrm{K}_{o}\right)$ и растениях ( $\mathrm{A}_{T i}$ Potentilla bifurca) 
вали среднее значение содержание каждого металла в почве для каждой пары проб (в слое 0-5 см и 10-15 см).

\section{Результаты и обсужление}

В диаграммах (рис. 1-9) представлены коэффициент опасности $\mathrm{K}_{о}$ (для $\mathrm{Ti}, \mathrm{Mn}, \mathrm{Cr}, \mathrm{Fe}, \mathrm{Ni}, \mathrm{Cu}, \mathrm{Zn}, \mathrm{Pb}$ и $\mathrm{Sr}$ в почве, в каждом из рассмотренных слоев) и коэффициент биологического поглощения $\mathrm{A}_{x}$ тех же металлов $P$. bifurca (приведены точки, для которых проанализированы содержания ТМ и в почвенных пробах, и в образцах лапчатки вильчатой) для сравнения аккумуляции ими поллютантов.

Участки отбора почвенных и растительных проб, обозначенные на рисунках 1-9: т14-2 км к северу от ТЭЦ-3, 1 км на с-в от ПНХ3, 7,5 км к северу от ПФ ТОО Кастинг; т21-3,6 км на запад от ТЭЦ-3 и ПНХ3, 6 км к с-3 от ПФ ТОО Кастинг; т27-5 км к северу от АО ТНК Казхром, 3 км к северу от АО ЕЭК, 20 км к западу от АО АК; т28-3 км к северу от АО ТНК Казхром, 1 км к северу от АО ЕЭК, 20 км к западу от АО АК; т30-1,5 км к северу от АО ТНК Казхром, 1 км к югу от АО ЕЭК; т31-0,5 км к востоку АО ТНК Казхром, 2,5 км к югу от АО ЕЭК; т34-8 км к югу от АО ТНК Казхром, 10 км к югу от АО ЕЭК; т35-25 км к югу от АО ТНК Казхром, 27 км к югу от АО ЕЭК; т38-5 км южнее АО АК; условнофоновая точка т44-50 км к северу от Павлодара, 40 км к северу от ПНХ3, 46 км на север от ПФ ТОО Кастинг.

Для $\mathrm{Cr}$ максимумы содержаний металла в почвенных и растительных пробах отмечаются в т31, несколько менее - в т27 и т30; среднее значение коэффициента биологического поглощения (КБП) $\mathrm{A}_{C r}$ составляет 1,1 (максимальное значение - 8,34, минимальное - 0,08), что означает достаточно высокую способность Potentilla bifurca накапливать данный элемент. Содержание этого поллютанта велико и в большей части почвенных проб (максимум - 10,44, минимум - 0,96 ПДК).

Для Zn также есть точки совпадений максимальных/ повышенных значений рассматриваемых коэффициентов и для почвы, и для растений - т31 и т34, но при этом в почве содержание металла - чуть более 0,6 ПДК, тогда как в растениях среднее значение $\mathrm{A}_{Z n}$ составляет 1,3, что свидетельствует о высокой аккумуляционной способности P. bifurca в отношении и этого поллютанта (максимум $\left.A_{Z n}=3,41\right)$.

Концентрации $\mathrm{Pb}$ в почве - 0,75-1,55 ПДК (максимум - в т30, т27). При этом для лапчатки коэффициент биологического поглощения невысок (средний $\mathrm{A}_{P b}$ равен 0,11, максимальное значение - в т38), т.е. для Pb coвпадений точек с высокими/низкими концентрациями в почве и растениях не отмечается, P. bifurca этот элемент аккумулирует слабо.
Fe - содержание в почве ниже фоновых только в т38, в остальных - равны концентрациям в т44 или превышают их; в растениях по сравнению с ними - весьма малы (средний $\mathrm{A}_{F e}$ равен 0,06); и этот металл P. bifurca аккумулирует незначительно, совпадений в точках с наибольшими / наименьшими концентрациями также не обнаружено.

$\mathrm{Sr}$ - содержание в почве не слишком значительно (около 0,55 ПДК), при этом в растениях среднее значение $\mathrm{A}_{S r}$ составляет 0,36 (что выше, чем аналогичный показатель для $\mathrm{Mn}, \mathrm{Ni}, \mathrm{Pb}, \mathrm{Cu}$, и особенно - Fe и Ti). То есть аккумулировать стронций $P$. bifurca способна, но при этом точек совпадений минимальных или максимальных концентраций элемента для растительных и почвенных проб не отмечается.

Содержание Ni в почве выше (от 0,53 до 0,82 ПДК), чем в растениях - коэффициент биологического поглощения составляет от 0,06 до 0,37, среднее значение $\mathrm{A}_{N i}$ невелико - 0,13, но совпадают наибольшая (в т31) и одна из меньших (в т44) концентраций поллютанта в почве и растительных пробах. Все же P. bifurca аккумулирует этот металл слабо.

Mn - и в почве (от 0,3 до 0,56 ПДК), и в образцах лапчатки вильчатой концентрируется не слишком активно (среднее $\mathrm{A}_{M n}$ составляет 0,24), совпадений минимума / максимума содержаний этого элемента в одних точках в почве и в растениях мы не отмечаем.

Концентрации Сu в почве находятся в пределах от 0,5 до 0,55 ПДК, в растениях содержания этого металла очень малы (среднее $A_{C u}=0,07$, что чуть выше, чем для Fe $и$ Ti).

Для Ті коэффициент опасности перехода его из почвы в растения - примерно на уровне $\mathrm{Ni}$ (от 0,46 до 0,77 ПДК); среднее значение КБП P. bifurca этого элемента составляет 0,06 и так же, как и среднее значение КБП для $\mathrm{Fe}$, является самым невысоким из всех рассмотренных нами металлов; совпадений в точках минимума/максимума концентраций Fе для проб почв и растений нами не выявлено.

Высокие значения $\mathrm{A}_{Z n}$ показаны в 6 из 10 рассмотренных нами точек (т14, т34, т31, т21, т27, т35), для $\mathrm{A}_{C r}$ - в 3 из 10 (т31, т34 и т27), совпадения высоких концентраций, таким образом, наблюдаются в точках т27, т31, т34; при этом значения КБП выше 1 для $\mathrm{Cr}-$ в диапазоне от 1,28 до 8,34, а для $Z n$ - от 1,03 до 3,41. Среднее значение КБП выше для $\mathrm{Zn}$, чем для $\mathrm{Cr}(1,3$ и 1,1 соответственно). Также среднее значение КБП выше для Sr $(0,36)$ и $\mathrm{Mn}(0,24)$, чем для остальных металлов. 
Чаще всего максимальный/очень высокий уровень (среди рассматриваемых нами концентраций) содержания в образцах растений и почв анализируемых элементов показан для т31 (Cr, Zn, Pb и Ni). $\mathrm{Mn}$ - только в растительных пробах; $\mathrm{Fe}, \mathrm{Ti}$ и $\mathrm{Sr}$ - в почвенных. Для т38- $\mathrm{Cu}, \mathrm{Ti}$ и $\mathrm{Fe}$ в лапчатке. Для т30- $\mathrm{Cr}, \mathrm{Pb}, \mathrm{Zn}, \mathrm{Fe}, \mathrm{Ti}, \mathrm{Ni}, \mathrm{Mn}$ в почве.

Невысокие концентрации $\mathrm{Ni}$ в образцах и растений, и почв отмечены в т44, Cr - в т14; для остальных поллютантов совпадений концентраций в системе «почва растение» нет. Наименьшие (или одни из минимальных среди наших проб) уровни $\mathrm{Cr}, \mathrm{Zn}, \mathrm{Pb}, \mathrm{Fe}, \mathrm{Ni}$ в лапчатке в т44; в т30 - Zn, Pb, Fe, Ti, Ni. B почвенных образцах минимумы концентраций $\mathrm{Zn}, \mathrm{Pb}, \mathrm{Fe}, \mathrm{Ti}, \mathrm{Ni}-$ в т38; в т14-Cr, $\mathrm{Sr}, \mathrm{Ni}$.

В рассмотренных слоях почвы загрязняющие вещества распределяются следующим образом: в 48\% случаев $\mathrm{K}_{o}$, а, значит, и концентрация металла в почвенной пробе выше в слое 10-15 см; в 40\% случаев - в слое 0-5 см, и в 12\% - концентрации в слоях одинаковы. В техногенных территориях (без учета типа почв), максимальные концентрации поллютантов, поступающих от ТЭЦ и предприятий металлургии, отмечаются в верхнем почвенном горизонте (до 10-20 см), контактирующем с приземным слоем атмосферы $[24,25,1,26]$. Этому способствует подщелачивание среды за счет ингредиентов, присутствующих в выбросах [27].

Меньшие значения поглощения $P$. bifurca поллютантов отмечаются в основном 50 км к северу от Павлодара (40 км к северу от ПНХ3, 46 км на север от ПФ ТОО Кастинг) - для $\mathrm{Cr}, \mathrm{Zn}, \mathrm{Pb}, \mathrm{Fe}, \mathrm{Ni}$; в 1,5 км к северу от АO THK Казхром (1 км к югу от АО ЕЭК) - для $\mathrm{Zn}, \mathrm{Pb}, \mathrm{Fe}, \mathrm{Ti}, \mathrm{Ni}$; $\mathrm{K}_{o}$ в почве - в основном - в 5 км южнее AO AK ( $\mathrm{Zn}, \mathrm{Pb}$, $\mathrm{Fe}, \mathrm{Ti}, \mathrm{Ni}$ ) и в 2 км к северу от ТЭЦ-3 (1 км на с-в от ПНХ3, 7,5 км к северу от ПФ ТОО Кастинг) - Cr, Sr, Ni. To есть точек совпадений минимальных значений $\mathrm{K}_{o}$ и $\mathrm{A}_{x}$ практически нет.

Наибольшие значения коэффициента биологического поглощения отмечаются в 0,5 км к востоку AO THК Казхром (2,5 км к югу от АО ЕЭК) для $\mathrm{Cr}$, Zn, Pb и $\mathrm{Ni}$ - и в $P$. bifurca, и коэффициента опасности $\mathrm{K}_{o}$ в почве. Там же - для $\mathrm{Mn}$ - только в P. bifurca; для $\mathrm{Fe}, \mathrm{Sr}$ и Ті - только $\mathrm{K}_{o}$ в почве. В 5 км южнее АО АK - для $\mathrm{Cu}, \mathrm{Ti}$ и Fe в $P$. bifurca (там же- минимумы $\mathrm{K}_{o}$ в почве для $\mathrm{Zn}$, $\mathrm{Pb}, \mathrm{Fe}, \mathrm{Ti}, \mathrm{Ni}$ ). B 1,5 км к северу от АО ТНК Казхром (1 км к югу от АО ЕЭК) - для $\mathrm{K}_{o} \mathrm{Cr}, \mathrm{Zn}, \mathrm{Pb}, \mathrm{Fe}, \mathrm{Ti}, \mathrm{Mn}, \mathrm{Ni}$ в почве (там же - минимумы КБП Zn, Pb, Fe, Ti, Ni P. bifurca).

\section{Зак^ючение}

Высокие значения коэффициента опасности загрязнения почв металлами $\mathrm{K}_{o}$ отмечаются на расстоянии до 5 км от промзон. Наибольшие значения коэффициента биологического поглощения $\mathrm{A}_{x} P$. bifurca $\mathrm{Cr}, \mathrm{Zn}$, $\mathrm{Pb}, \mathrm{Ni}$, а также $\mathrm{Cu}$, Ti и Fe показаны на участках в 0,5-5 км от действующих предприятий. Распространение поллютантов соответствует направлению преобладающих ветров, в основном снижаясь с увеличением расстояния от источников загрязнения.

Zn и Cr накапливаются в P. bifurca более активно, чем $\mathrm{Sr}$ и $\mathrm{Mn}, \mathrm{a} \mathrm{Ni}, \mathrm{Pb}, \mathrm{Cu}, \mathrm{Ti}, \mathrm{Fe}$ - в довольно незначительных количествах. Так, среднее значение $\mathrm{A}_{C r}$ составляет 1,1 (максимальное - 8,34, минимальное - 0,08); среднее значение $A_{Z n}=1,3$ (максимум - 3,41, минимум - 0,47). При этом очевидного эффекта от воздействия на лапчатку высоких концентраций этих металлов не наблюдается (вероятно, есть какие-то изменения на уровне анатомии, но этот аспект нами не исследовался). Отмечены металлы, которые почти не накапливаются в растительных организмах даже при их значительном содержании в почве (Pb: при среднем $\mathrm{K}_{o}$ в почве, равном 1, среднее значение $\mathrm{A}_{P b}$ P. bifurca составляет всего 0,11).

Potentilla bifurca, как вид дигрессионно-активный, в техногенных регионах часто становится субдоминантом вторичных растительных сообществ, хотя в естественных фитоценозах этих территорий она практически не встречалась. Способность лапчатки вильчатой к аккумуляции Zn и Cr можно использовать для определения наличия загрязнения среды в техногенных регионах, в частности, в районах расположения металлургических предприятий. При этом необходимо учитывать возраст растений, расстояние от источника выброса загрязняющих веществ, погодные условия, особенности нанорельефа.

\section{Результаты}

наших исследований могут быть использованы при изучении состояния окружающей среды регионов Казахстана, России и других стран при совпадении условий и факторов воздействия.

\section{ЛИТЕРАТУРА}

1. Панин М. С. Химическая экология / [Ред. С. Е. Кудайбергенова]. - Семипалатинск: СГУ им. Шакарима, 2002. - 852 с.

2. Воривохина Н. М. Аккумуляция тяжелых металлов почвами и растениями под воздействием природных и техногенных факторов в районе угольного месторождения «Каражыра» (Республика Казахстан, Восточно-Казахстанская область): автореферат дис. ... канд. биол. наук.— Самара, 1998.— 24 с. 
3. Панин М. С. Аккумуляция тяжелых металлов растениями Семипалатинского Прииртышья.— Семипалатинск: ГУ «Семей», 1999. — 309 с.

4. Султанова Б. М. Антропогенная трансформация растительности Семипалатинского испытательного полигона: дис. ... канд. биол. наук: спец. 03.00.05 Ботаника.- Алматы, Институт ботаники и фитоинтродукции, 2000.- 250 с.

5. Бигалиев А.Б., Шаймарданова Б. Х. Городская растительность в качестве биоиндикаторов техногенной нагрузки // Вестник КазНУ им. Аль Фараби. Серия экологическая. - 2005.—№ 1 (16). - С. 20-25.

6. Демич Ю. А. Содержание тяжелых металлов в объектах окружающей среды и состояние растительных популяций // Вестник Самарского государственного университета. Естественнонаучная серия.— 2006. № 7 (47). — С. 45-53.

7. Копылова Л. В. Накопление тяжелых металлов в древесных растениях на урбанизированных территориях Восточного Забайкалья: автореферат дис. .... канд. биол. наук: 03.02.08. - Улан-Удэ, 2012.— 24 с.

8. Корельская Т.А., Попова Л. Ф. Тяжелые металлы в почвенно-растительном покрове селитебного ландшафта города Архангельска // Арктика и север.2012.—№ 7.—C. 1-17.

9. Гашкова Л.П., Иванова Е. С. Аккумуляция тяжелых металлов в растениях-доминантах антропогенно-нарушенных участков болот на территории Томской области // Известия Самарского научного центра Российской академии наук. — 2014. — Том 16, № 1 (3). — C. 732-735.

10. Каротеева Е.В., Веселкин Д. В., Куянцева Н. Б. и др. Накопление тяжелых металлов в разных органах березы повислой возле Карабашского медеплавильного комбината // Агрохимия. — 2015.— № 3.- С. 88-96.

11. Хачатрян Л.Р., Нерсисян Г.С., Григорян М. А. 0 концентрации тяжелых металлов в листьях вяза малого, произрастающего на территории г. Еревана // Антропогенная трансформация природной среды.— Пермь: Пермский государственный национальный исследовательский университет, 2016. 一 № 2.— C. 250-254.

12. Ташекова А.Ж., Торопов А. С. Использование листьев растений как биогеохимических индикаторов состояния городской среды // Известия Томского политехнического университета. Инжиниринг георесурсов.-2017. - Т. 328, № 5.—C. 114-124.

13. Леонова Ю. М. Антропогенная трансформация растительности в зоне влияния промышленных объектов г. Павлодара: дис. ... канд. биол. наук: спец. 03.00.05 Ботаника. - Алматы: Институт ботаники и фитоинтродукции, 2010. — 157 с.

14. Козыренко М.А., Каниболоцкая Ю. М. Тяжелые металлы в почве и растениях // ХІІ Сатпаевские чтения: Матер. международ. науч. конф. (Павлодар, 12 апреля 2012 г.). - Павлодар, 2012.—C. 182-185.

15. Берикова А.Т., Каниболоцкая Ю. М. Антропогенная трансформация растительного покрова в зоне воздействия АО «ЕЭК» и АО «ТНК «Казхром» // IX Торайгыровские чтения: Матер. международ. науч. конф. (Павлодар, 10 октября 2017 г.).— Павлодар, 2017. — C. 75-78.

16. Биогеохимические и геоботанические исследования.-Л.: Недра, 1972.- 280 с.

17. Методические рекомендации по проведению полевых и лабораторных исследований почв при контроле загрязнения окружающей среды металлами.М.: Гидрометеоиздат, 1981. - 109 с.

18. Полевая геоботаника в 4-х томах / [Ред. Е. М. Лавренко и А. А. Корчагин].— М.—Л: Наука, 1959-1972.— 1805 с.

19. Kloke A. Richwerte 80. Orientierungsdaten fur tolerierbare Gesamtgehalte einiger Elemente in Kulturboden // MitteilungerVDLUFA. - 1980.—H. 1-3.—P. 9-12.

20. Научно-методические указания по мониторингу земель Республики Казахстан. - Алматы: Галым, 1993.— 108с.

21. Санитарные нормы допустимых концентраций химических веществ в почве. СаН и П, № 2546-82 от 13.05.83.

22. Руководство по санитарно-химическому исследованию почвы (нормативные материалы).— М.: ЦНИИ Электроника, 1993. - 129 с.

23. Перельман А. И. Геохимия ландшафта.— М.: Географгиз, 1961. — С. 23-481.

24. Ильин В. Б. Тяжелые металлы в системе «почва-растение».—- Новосибирск: Наука. Сиб. отделение, 1991.—151 с.

25. Мудрый И. В. Тяжелые металлы В системе «почва — растения — человек» // Гигиена и санитария. — 1997.—№ 1.— С. 14-17.

26. Лузгин Б. Н. Загрязнение почв металлами (на примере Алтайского региона) // География и природные ресурсы.— 2004.— № 3.— C. 151-154.

27. Сает Ю.Е., Ревич Б. А., Смирнова Р.С. и др. Город как техногенный субрегион биосферы // Труды биогеохимической лаборатории.- М.: Наука, 1985.T. 20.- C. 133-165.

(c) Каниболоцкая Юлия Михайловна ( yu_leonova@mail.ru ).

Журнал «Современная наука: актуальные проблемы теории и практики» 